\title{
Arabian plate oil and gas: Why so rich and so prolific?
}

\author{
Department of Geology, American University of Beirut, Lebanon
}

\begin{abstract}
The Arabian plate region (roughly the Arabian Peninsula, the Fertile Crescent and SE Turkey and SW Iran south of the Taurus/Zagros Mountains) contains 66.4\% and $33.9 \%$ of the world's recoverable oil and gas reserves as of the start of 1998 . Over $98 \%$ of these reserves are located along the NE Arabian shelf margin stretching from Iraq to Oman. The reasons behind this richness in hydrocarbons are examined. Some of the factors responsible for such richness include the presence of many petroleum systems over geological time including repeated and extensive source rock beds, excellent carbonate and some sandstone reservoirs in good juxtaposition, excellent regional seals, huge anticlinal traps and a long history of almost uninterrupted sedimentation. The critical factor, however, is the areal extent of the NE margin shelf reaching $2000 \mathrm{~km}$ in width and nearly $3000 \mathrm{~km}$ in length, for which there is no modern analogue. A plea is made for an immediate input of $R$ and $D$ funds to establish a commercially viable energy alternative( $s$ ) to this finite valuable resource (feedstock for the petrochemical industries and a huge source of synthetic proteins) which is due to run out in about 43 years at the present day rate of consumption.
\end{abstract}

\section{Introduction}

At the start of 1998, the Arabian plate region of the Middle East contained about $66.4 \%$ of the world's recoverable oil reserves and about $33.9 \%$ of the recoverable gas reserves (Figure 1). In this paper, the Arabian plate consists of the Arabian Peninsula (including the Persian-Arabian Gulf) and the countries of the Fertile Crescent. The latter include SE Turkey and SW Iran lying south and southwest of the Taurus and Zagros suture zones (which welded Arabia to Eurasia some 10 to 5 million years ago) and east of the Levant fracture system (or Dead Sea) transform running from the Gulf of Aqaba of the Red Sea northward to the Taurus Mountains of Turkey. Prior to the rifting and opening of the Gulf of Aden and the Red Sea in the late Oligocene to earlier Miocene (ca. 25-15 million years ago) and the formation of the Levant fracture system transform, the western boundary of the Arabian plate extended into the eastern Mediterranean (Figure 2).

Arabian plate recoverable oil reserves at the start of 1998 were estimated at about 677 billion barrels (ca. 90 billion metric tons) and its gas reserves at 1725 trillion cubic feet (ca. 49.3 trillion $\mathrm{m}^{3}$ )(Oil and Gas Journal, 29 Dec. 1997). These figures constitute, as already indicated, $66.4 \%$ and $33.9 \%$ of the world's recoverable oil and gas reserves respectively. The overwhelming part of these reserves, however, namely $98.99 \%$ of the oil and $98.52 \%$ of the gas, are located in the NE Arabian plate margin shelf (and in Oman) in what is called the Iraq-Iran-Arabia basin which extends from NW Iraq through eastern Arabia and SW Iran and the Persian-Arabian Gulf waters into Oman (Figure 2). The bulk of the reserves are located in eastern Saudi Arabia, Iraq, Kuwait, SW Iran and Abu-Dhabi, with the remaining Gulf countries and Oman possessing $2.94 \%$ of the oil reserves. Over 65\% of the gas reserves are located in Qatar and SW Iran due to the presence of Qatar's "megagiant" North Dome offshore gasfield (the largest single gas field in the world) and to SW Iran's several "supergiant" onshore and offshore gas fields which give these two countries the largest share of Arabian plate gas reserves amounting to about $46.95 \%$.

Compared with other major hydrocarbon-rich country groupings or individual countries in the rest of the world, each of the five Middle East countries possessing the bulk of NE Arabian shelf oil reserves has a higher share than any of the nearest claimants singly (and often collectively) elsewhere in the world, including the former Soviet Union; Saudi Arabia's oil share alone constitutes 25.4\% of the world's total reserves. Take some examples from other "big league" players around the world, we may find that in the western hemisphere Venezuela holds $7.02 \%$, Mexico $3.92 \%$, the U.S.A. $2.15 \%$ and Canada $0.47 \%$ of the world's total recoverable oil reserves and that the U.S.A., Venezuela and Canada hold 3.27\%, $2.81 \%$ and $1.27 \%$ of the world's gas reserves respectively. In Africa, Libya has $2.89 \%$, Nigeria $1.64 \%$, Algeria $0.9 \%$, Angola $0.53 \%$ and Egypt $0.38 \%$ of the world's oil reserves with Algeria and Nigeria respectively holding $2.56 \%$ and $2.26 \%$ of the world's gas reserves. In Europe, Norway and the United Kingdom respectively hold $1.02 \%$ and $0.49 \%$ of the world's oil reserves and $1.02 \%$ and $0.52 \%$ of its gas reserves with the Netherlands holding $1.20 \%$. In Asia, China, India, Indonesia and Malaysia respectively hold $2.35 \%$, $0.42 \%, 0.49 \%$ and $0.38 \%$ of the world's oil reserves with Indonesia and Malaysia respectively holding $1.42 \%$ and $1.57 \%$ of the world's gas reserves. The former Soviet Union countries hold $5.61 \%$ of the world's oil reserves but $38.56 \%$ of its gas reserves (Figure 1)(Oil and Gas Journal, op. cit.).

Compared with countries that have made "giant"-sized (and above) oil discoveries, in the continental U.S.A./Alaska for example, the number of fields discovered over the years holding initial recoverable reserves of $>0.5$ billion barrels of oil does not exceed 48 , with the East Texas field being the largest in the 48 states, holding over 5.3 billion barrels, and the Prudhoe Bay in Alaska holding about 12 billion barrels. In the Middle East, the comparable number is 149 with two "megagiants" exceeding 50 billion barrels and 27 "supergiants" out of the world's total of 40. The rest of the "supergiants" are located in Latin America (five), the former Soviet Union (four), the U.S.A. (two), China and Africa (one each).

What then makes the Arabian plate region of the Middle East and particularly its NE Arabian shelf so rich and so unique in its hydrocarbon reserves, especially oil? Before addressing the question, an example from the region that vividly illustrates this richness is worth restating. 


\section{Figure 1 World hydrocarbons reserves by percentage, estimated at the start of 1998}

$\mathrm{A}=98.99 \%$ of total oil and $98.52 \%$ of total gas reserves of the Arabian plate are located in NE margin shelf countries to Oman $\mathrm{B}=$ Venezuela, Mexico, U. S. A., Canada, Brazil

$\mathrm{C}=$ Libya, Nigeria, Algeria, Angola, Egypt

D=Norway, U. K., The Netherlands

$\mathrm{E}=\mathrm{China}$, India, Indonesia, Malaysia

$\mathrm{F}=$ Former Soviet Union

$\mathrm{G}=\mathrm{All}$ other countries

Note: The Netherlands contributes little to the world's oil reserves and Angola little to the gas.
On 22nd February 1991, retreating elements of the Republican Guard of the Iraqi forces in Kuwait began destroying the oil wells and setting them on fire. By the time they had finished, 727 wells were out of control, most of them fiercely burning. The rapidly rising thick columns of dense black smoke billowing up into the upper atmosphere soon obliterated the sun; the atmospheric pollution from fine particulates, ash and gases was rapidly carried round the world. The number of wells blazing or those gushing out of control across the desert to form shallow black oil lakes around and in which most forms of life died, constituted over half of the total oil producing wells of Kuwait distributed amongst half a dozen or so fields including the "megagiant" Burgan field.

The resulting inferno from such fierce heat must have been the closest thing to hades that the fire fighting teams (who began their attempts at extinguishing the fires soon after hostilities ended) must have experienced and survived. It would have seemed at the time that the task of extinguishing all the fires and bringing all the wells under control was an unaccomplishable one as the high reservoir pressure deep down below the surface where the oil is trapped, brought the now uncontrollable flow gushing high above the ground. Yet, on 6th November 1991, the last fire was extinguished and the last well brought back under control, the mighty roar of gushing flow and the fiercely burning oil being at last silenced thanks to the skill and daring of several international oilwell fire fighting specialists and the discipline of their teams.

Estimates of the total amount of oil squandered through this act according to various media reports and estimates of specialists during media interviews have varied between 2 and 6 million barrels per day. If one averages these two extremes and accepts that 4 million barrels (ca. 531000 metric tons/day) were probably an acceptable estimate, the total oil lost over the 258 days during which the Kuwait wells were running wild would be 1032 million barrels (ca. 137 million metric tonnes). This total, however, is most probably less, since with time progressively more out of control wells were successfully "killed" and capped diminishing the daily uncontrolled flow. Moreover, most of the crude oil that had not ignited but had formed lakes over the desert floor was later recovered during clean-up operations with a major portion still utilisable in one way or another. Nevertheless, if the figure of the total oil lost is rounded off to 1 billion barrels, this would represent about $1.06 \%$ of Kuwait's proven recoverable oil reserves as of the end of 1997 . The 1 billion barrels lost represent, in turn, just about 15.4 days of oil consumption on a worldwide basis, currently running at 64.9 million barrels/day (ca. 8.6 million metric tonnes/day).

\section{Arabian plate hydrocarbon systems}

For any hydrocarbon accumulation to occur, all elements that collectively make up the petroleum system responsible for its existence must be present, otherwise no "commercial" accumulation is possible. There have been several definitions of the term "petroleum system" which are in general quite similar to each other. The one proposed by McGoon and Dow (1994) has been utilized here for its succinctness, clarity and up-to-dateness.

A petroleum system is a natural system that encompasses a "pod" of active source rock that is generating and expelling petroleum at the critical moment of maximum burial depth (at which temperature can activate the conversion of organic matter in the source rock) and all related oil and gas. This includes all the geological elements of source rocks, reservoir rocks, seal rocks and overburden rocks, the process of trap formation and the generation, migration and accumulation of petroleum. The term "system" describes the independent elements and processes that form a functional unit that creates hydrocarbon accumulations. The essential elements and processes must occur both in time and space that organic matter included within a source rock can be actively converted into a petroleum accumulation; a once active source rock may now be inactive or depleted. Thus, a mature source rock, namely one that has become active, is the critical element that is essential for any hydrocarbon generation of oil or gas in the source rock and for expulsion into a carrier reservoir bed and migration and accumulation into a sealed trap. Thus without source maturity, no generation takes place and no commercial accumulations is possible even if all the other elements and processes of reservoir, trap and seal are present.

The "pod" of active source rock is the provenance for the series of genetically related petroleum shows, seepages and accumulations in the petroleum system. The genetic relationships between a particular source rock and the petroleum it generated are established through a petroleum-source rock correlation and then the system is delineated by mapping its geographical boundary, which circumscribes the distribution of the active source rock in a sedimentary basin and all shows, seepages and accumulations that originated from it. The time over which the process of generation and migration of petroleum took place and shows, seepages or accumulation occurred is the age of that specific petroleum system.

The Arabian plate is blessed with many petroleum systems based on a large number of areally extensive active source rocks. Murris (1980) discussed some of the main Mesozoic source rocks of the Arabian-Persian Gulf region, while Stoneley (1990) reviewed the main Mesozoic to Early Cenozoic rocks for the NE Arabian shelf; Beydoun (1991, 1993) and Beydoun et al., (1992) greatly 
expanded on this, whilst Beydoun (1995) covered all identified source rocks for the entire Arabian plate region of the Middle East in connection with a discussion on productive Middle East sandstone reservoirs and origins of their hydrocarbons. Figure 3 shows all the identified source rocks in the NE Arabian shelf region and Oman (where over $98 \%$ of the reserves are from the Infra-Cambrian to the Miocene), in relation to the productive reservoir rocks (mainly carbonates but with sandstones differentiated) and highlights the stratigraphic position of the regional evaporite seals. Figure 4 represents a schematic SW-NE cross section across the NE Arabian shelf from the Arabian shield to the Zagros suture zone indicating the very thick sedimentary column that covers much of this very petroliferous region and also showing the stratigraphic positions of the main regional evaporite seals. The position of the Zagros foreland basin with its huge "whaleback" anticlines, overprinted onto the NE Arabian passive margin shelf during the Neogene is also shown.

These vast oil (and to a lesser extent gas) reserves of the Arabia plate region are housed in huge to large structural (anticlinal) traps in extensive porous and permeable limestone and (more subordinately) sandstone reservoirs with generally large drainage areas and under efficient seals. In general, reservoir pressures are high with abnormally high pressure zones also being encountered at times. It is very rarely the case that reservoirs have to have their oil pumped to the surface because of lack of pressure (the Saudi-Kuwaiti Neutral zone and some of the Yemeni fields are some of these rare exceptions). The oil and water (and free gas, if the oilfield is gas-saturated) are separated from each other by their different densities/buoyancies and their relative immiscibility (although gas dissolves in oil under certain higher pressures and rapidly separates out under lower pressures) into distinct zones with the denser fluid water at the bottom, oil in the middle and gas at the top and with sharp to diffuse contacts between those zones.

\section{Arabian plate historical geology: The reason behind its hydrocarbon richness}

The factors responsible for richness in hydrocarbons and especially oil in the Arabian plate have been discussed by many geologists in the last two decades (e.g. Dunnington (1974), Grunau (1977), Riché and Prestat (1979), Murris (1980), Bois et al. (1982), and Beydoun (1986, 1988, 1991, 1993). These factors include: (a) large areas of high-quality source rocks preserved in different intervals of geological time, especially during the Mesozoic, when the region was in warm latitudes with high organic productivity; (b) a long and almost uninterrupted history of sedimentation; (c) the development of juxtaposed source and reservoir facies belts which facilitated hydrocarbon expulsion and migration over long distances; (d) tectonic fracturing of better, younger, stratigraphically higher carbonate reservoirs during the overprinting of the Zagros foreland basin in the Neogene to permit vertical migration into huge anticlines under efficient evaporitic seals. Murris (1980), however, identified the most outstanding factor, the extraordinarily extensive horizontal scale of the NE Arabian margin shelf and especially its width, reaching some $2000 \mathrm{~km}$ (Figure 2).

The type and areal distribution of the key element in each of the Arabian plate's diverse petroleum systems were principally influenced by the changing paleolatitudinal position of the region throughout the Phanerozoic. During the Paleozoic, the Arabian plate was located in the southern hemisphere as part of the northern passive margin of Gondwanaland and principally in high latitudes with predominance of clastic sedimentation. Deposition of organic-rich shales was thus primarilly controlled by global transgressions. During the Mesozoic and Cenozoic, the Arabian plate was principally in tropical regions where carbonate deposition prevailed and organic productivity was high. Source rocks were, in consequence, mainly organic-rich carbonates or organic-rich argillaceous sediments. Figure 4 illustrates this principle and shows the changing position of the
Kuwait-Basra area (roughly in the middle of the NE Arabian margin shelf) during the period from the start of the Phanerozoic until the present.

Arabian plate margins in general and the NE Arabia shelf margin in particular have had a long and almost uninterrupted history of sedimentation since the close of the Proterozoic (Late Precambrian) some $570 \mathrm{Ma}$ ago. There have been no major orogenic movements (with strong folding and thrusting and accompanying metamorphism and igneous activity) throughout most of this time although epeirogenic vertical movements occurred stripping sediments from the elevated areas, especially during the Paleozoic. The late"Alpine" phase was the first orogenesis when the northern and NE Arabian margins and shelves collided and sutured with Eurasia; this event started during the Late Eocene some $40 \mathrm{Ma}$ ago with the gradual oblique closure of the Neo-Tethys Ocean (Hempton, 1987). The collision culminated in the Miocene-Pliocene (6-2 Ma ago). Compression from this collision which overprinted the Zagros foreland basin on the NE Arabian margin shelf is still being exerted through the additional stresses produced by the opening of the Gulf of Aden and the Red Sea (some $25 \mathrm{Ma}$ ago) resulting in separation of Arabia from Africa and its propulsion and rotation northeastward against Eurasia; the Arabian plate is moving horizontally farther northward relative to the Sinai and coastal Levant plate along the Levant (or Dead Sea) transform fault. At the collisional front, the Taurus and Zagros mountain chains continue to rise as a consequence of this compression with deeper earthquake zones developing, whereas the transform or horizontal motion along the Levant (Dead Sea) fracture develops generally intermediate focus earthquakes (Figure 2).

The Arabian plate is thus bounded within a relatively small area of the globe by the three principal types of plate boundaries: (1) extensional (or accretional) boundary resulting from rifting and sea floor spreading in the Gulf of Aden and Red Sea in the south and west, thus creating new crust and embryonic ocean basins; (2) compressional or collisional boundary, where two continental plate margins (as in this case) converge and collide, giving rise to an orogenic mountain chain, one plate (the Arabian) underriding the other (Eurasian) to give rise to the Taurus and Zagros Mountains in the north and northeast and to the Oman Mounains in the southeast (where the collision occurs between a continental plate and an oceanic or a denser plate); this process shortens the plate edges by thickening and folding them; (3) transform or neutral plate boundary in the west along the Levant (Dead Sea) fracture, where the plates slide past each other laterally without adding or destroying crustal material; here the Arabian plate is moving horizontally northward relative to the Sinai-Levantine plate, where horizontal displacement magnitudes in the southern sector of about $107 \mathrm{~km}$ can be measured by the distance offset of formerly contiguous features sliced by the Dead Sea fault zone (Quennell, 1958, 1984) (Figure 2).

Apart from this major "collisional" event of the Neogene and an earlier but orogenically aborted Late Cretaceous event in which oceanic crust was subducted onto or overrode the outer margin of the Arabian shelf, the NE Arabian shelf region had a quiescent geological history from the close of the Proterozoic, interrupted from time to time by epeirogenic or broad vertical movements of elevation and subsidence; erosion and removal of sediments affected the uplifts and increased deposition in the subsidence areas and basins. These movements took place mainly in the rigid basement substrate making up the continental crust with the entire overlying sedimentary column draping more passively or parting more dynamically in the path of more mobile deeply buried salt sequences in response to density and overburden pressure differences and/or to horizontal motion in the basement creating compressional and tensional stresses in sectors of the overlying sediments.

\section{Arabian plate geological evolution}

Throughout the Paleozoic (570-245 Ma) the Arabian plate was attached to Africa and, with the adjacent blocks composed of the 


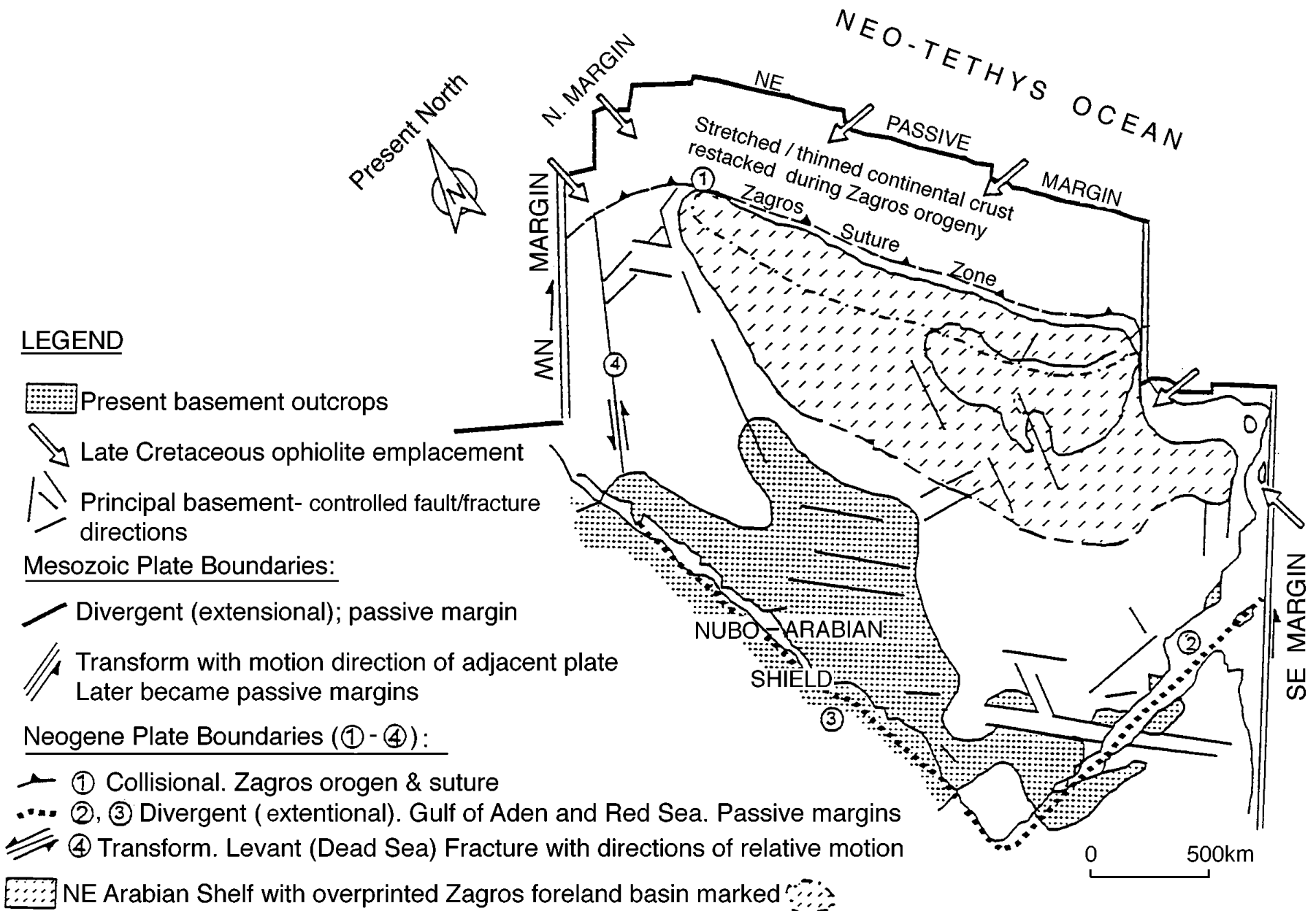

Figure 2 Conceptional sketch of the Arabian plate ("Arabian Promontory") from Jurassic to Eocene showing the principal plate boundaries then with new Neogene plate boundaries added and also indicating the width of the NE Arabian shelf then and now and principal tectonic features (modified with permission from M. W. Hughes Clarke, unpublished).

Turkish and Iranian continental fragments, it constituted part of the long-passive plate margin of Gondwanaland. Wide epeiric seas (situated on the continental shelf and into the continental interior) covered the region and advanced and regressed leaving behind mainly clastic deposits (sandstones, siltstones and clays). The region was mainly located in the southern hemisphere moving from equatorial waters to polar regions and back to tropical regions (Figure 5). Carbonate sediments were laid down during periods of drift into tropical latitudes. Two glaciation episodes affected parts of western and central Arabia in the Late Ordovician (ca. $480 \mathrm{Ma}$ ago) and southern Arabia during the Late Carboniferous-Early Permian (300-275 Ma ago) (Figure 5).

During the middle Permian and the Triassic to Jurassic (250 Ma $-160 \mathrm{Ma})$, extension and rifting broke off a succession of microplates from the northern and NE sectors of the Arabian portion of Gondwanaland (collectively known as the Cimmerian blocks) which drifted away as the Neo-Tethys Ocean opened and gave rise to the "Arabian Promantory" (Figure 2). By then, the region was back in tropical latitudes where carbonates became the main sedimentary deposits, with coarse clastics being confined to specific sectors of the NE Arabian shelf as a result of fluvio-deltaic deposition. Evaporites (anhydrite, halite, etc.) were sporadically laid down in response to arid climatic phases. Northward drift continued until the Arabian plate became entirely located in the northern hemisphere from the Late Paleocene (ca. 59 Ma ago). With loss of the Cimmerian blocks the NE Arabian shelf region occupied the frontal position in the Arabian sector of the new Gondwanan passive plate margin and its still very wide epeiric shelf.
During the Mesozoic (245-65 Ma) and the earlier part of the Tertiary (65-10 Ma), predominantly carbonate successions interspersed by fine clays were widely and repeatedly laid down over an incredibly wide shelf in a series of shallow intrashelf basins separated by broad shoals where more detrital carbonates, banks and reefs flourished; periodic restriction of water circulation on this very broad shelf resulted in evaporite deposition (Murris, 1980). Within the shallow basins, water density stratification gave rise to anoxic bottom conditions favorable to the preservation of organic matter derived from prolific organic productivity in warm surface waters; this resulted in the deposition of a succession of organic-rich source beds (Figure 3). The shallow basin margins and inter-basin platforms contained carbonate reservoir rocks (or in limited areas, ideally suitable fluvial-deltaic sandstone reservoir rocks such as those in the Kuwait-southern Iraq region), while periodic evaporites or regressive shales produced good seal or cap rocks as the sea retreated before re-advancing (eustatic falls and rises) (Murris, 1980). Thus, source/reservoir/seal rocks were repeatedly deposited in optimum juxtaposition both in space and in time, and oil migrated from the sources into the reservoirs under efficient seals and then moved into traps formed continuously either by basement fault block movements and overlying sedimentary drape folding or by periodically reactivated upward movement of deep-seated salt in response to overburden load forming piercement flank traps and doming of overlying sediments as salt growth anticlines (Figure 4) (Beydoun, 1991, 1993; Beydoun et al., 1992).

This Mesozoic-Tertiary succession was stacked over a thick Paleozoic one consisting predominantly of clastics which, despite 


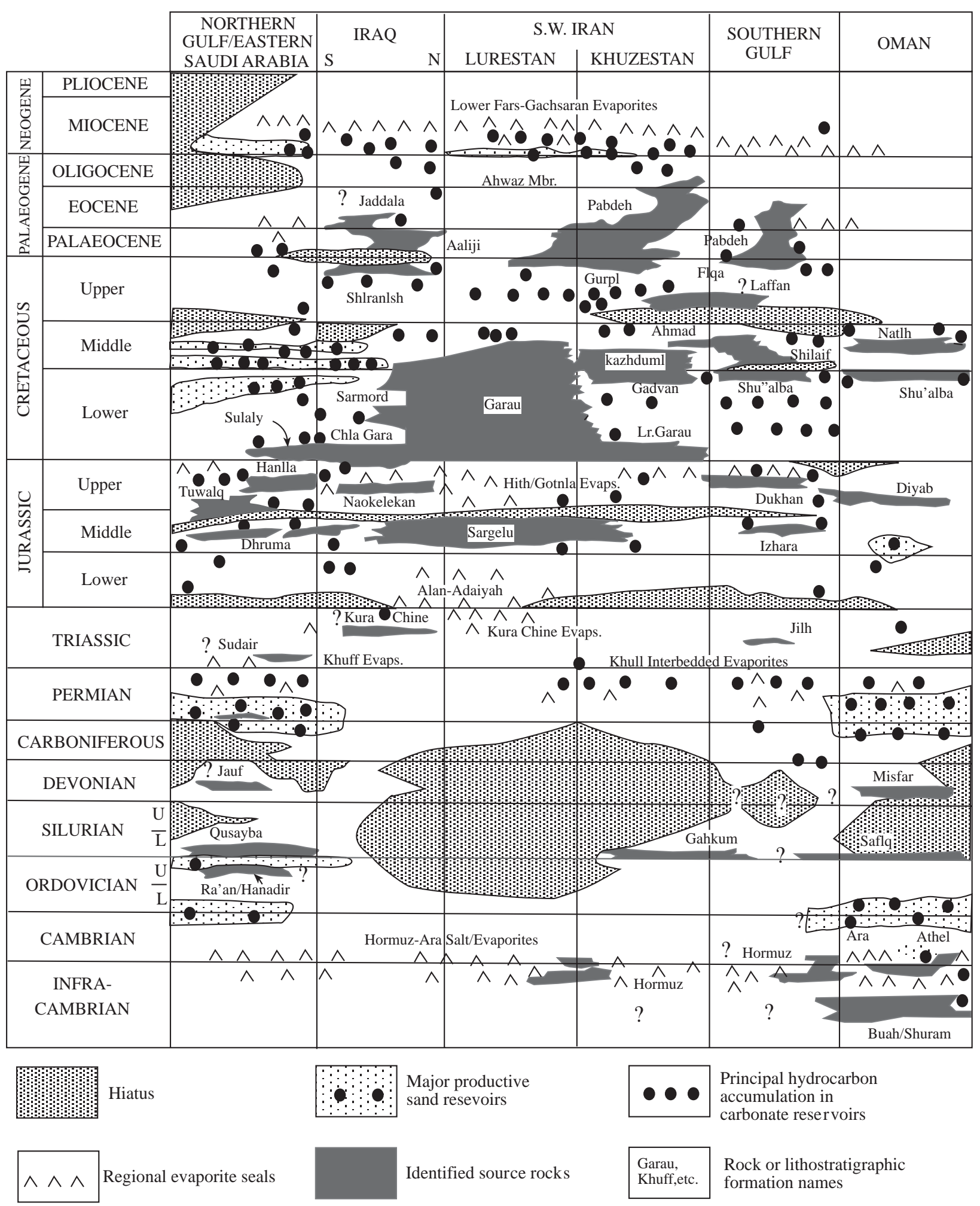

Figure 3 Stratigraphical position of the identified source rocks in the NE Arabian shelf region and Oman(expanded and modified from Stoneley, 1990 and Beydoun, 1993).

the occurrence of a lesser number of source beds, were more widely distributed as they were the products of transgression and global sea level rises. Alternatively, some were the product of Late Proterozoic rifting and characterized by more tropical organic productivity and the presence of good evaporite seals (Figures 3 and 4).

In the Neogene, as a consequence of the Zagros orogeny, giant NW-SE trending "whaleback" compressional anticlines were created, into many of which much oil and gas vertically migrated from deeper reservoirs and traps to accumulate in highly fractured Tertiary carbonate reservoirs under widespread evaporitic seals of Miocene age. As the rising Zagros mountain chain was further elevated by the orogenic compression, subsurface flow gradients changed and much remigration of oil occurred (Dunnington, 1974; Beydoun et al., 1992). But the most spectacular characteristic of the NE Arabian shelf was not the special richness of its source rocks, nor the highly developed porosity-permeability of its reservoirs, nor the 


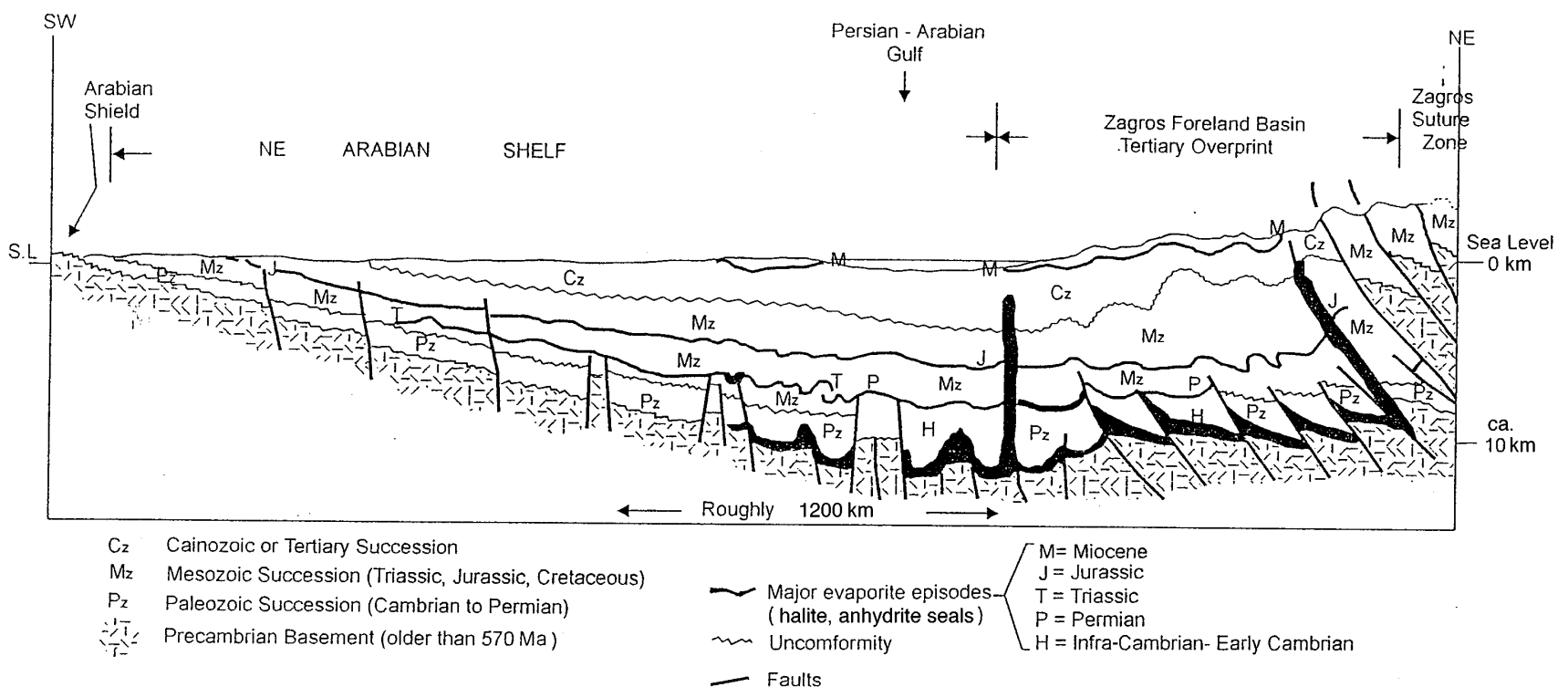

Figure 4 Schmatic section across the NE Arabian Shelf from the Arabian basement shield across the northern gulf and Zagros foreland basin to the Zagros suture zone.

extreme efficiency of its regional seals, but the combination of these areally over an extraordinarilly extensive shelf which was up to 2000 $\mathrm{km}$ in width and about $2700 \mathrm{~km}$ in length and for which there is no modern analogue (Murris, 1980) (Figure 2).

The Zagros orogeny and the earlier aborted Late Cretaceous collisional event played both negative and positive roles in the maturation and migration of oil over the outer edge of the NE Arabian shelf. At the close of the Cretaceous during the Campanian stage (ca. $75 \mathrm{Ma}$ ), a collision between the leading edge of the NE Arabian passive margin and probably an oceanic ridge (or possibly an island arc system) resulted in the obduction (overriding) across the more buoyant Arabian continental edge of the "Arabian Promontary" of denser oceanic crustal material in the form of an ophiolite belt; this belt extends discontinuously from Cyprus through NW Syria, SE Turkey, northern Iraq and SW Iran to Oman (Figure 2). In both Cyprus and Oman, there occur superb exposures of deeper crustal and upper mantle rocks. This collision did not lead to suturing; the orogeny was aborted owing to probable reversal of the plate motion direction and a return to shelf sedimentation. The tectonic event, however, provided an abnormal and sudden overburden load onto relatively still shallowly buried earlier Cretaceous source rocks, accelerating their maturation (through deeper burial and hence higher temperature) and resulting in unquantifiable loss of oil to the surface in Late Cretaceous to Paleogene times. The evidence for it can be found in bitumen impregnation of Upper Cretaceous reef limestones (ca. $70 \mathrm{Ma}$ ) and water-worn bitumen pebbles in some Paleocene-Lower Eocene conglomerates (65-50 Ma ago) along the Iraq-Iran border in the Zagros, indicating that a large oil accumulation(s) was/were undergoing dissipation at the time of deposition of these rocks (Beydoun et al., 1992). With the onset of the later collisional event of the Zagros orogeny, huge quantities of sedimentary bitumens spread over large areas of the Tigris basin of Iraq, impregnating. Miocene deposits through leakage from reactivated faults tapping reservoirs deeper down before they had developed as a seal (Beydoun et al., 1992).

The continent-continent collision between the Arabian and Eurasian plates starting in the Late Eocene (ca. $40 \mathrm{Ma}$ ) resulted in initial restacking and thickening of the continental crust of the Arabian plate (which had been thinned and extended during the Triassic rifting and drifting away of the Cimmerian blocks) and then overprinting of the outer passive margin shelf of the NE Arabian margin with a foreland depositional basin and a structural grid of highamplitude NW-SE trending "whaleback" anticlinal folds (Hempton, 1987; Beydoun et al., 1992). Tertiary deposition, as all these events were proceeding, added other excellent carbonate reservoirs to the succession (the Asmari Formation) capped by excellent and widely extensive evaporite seals (the Lower Fars and Gachsaran Formations) (Figure 3). As compressional stresses increased, stronger folding intensified fractures which developed in the more "rigid" and brittle carbonate successions of the Mesozoic-Tertiary, providing vertical conduits for oil to migrate upward and fill these newly created "whaleback" structures, simultaneously helping to accelerate maturation of the younger Upper Cretaceous and Lower Tertiary source rocks by extra down-buckle burial and add overburden load to the position where generation of oil began on a localised scale. Where the evaporite seal was breached by the intensity of folding or was eroded from the rising Zagros chain, the vertically remigrated oil seeped straight to the surface and dissipated with great surface hydrocarbon loss. Such evidence of loss has been noted since antiquity in the region and includes the "eternal fires" of the Kirkuk oil structure in Iraq caused by steady gas seepage spontaneously igniting at the surface. Oil seepages in the region have produced bitumen and tar deposits (oxidized crude oil which has lost its lighter hydrocarbon fractions) which were used to caulk boats or to manufacture artefacts or for medicinal purposes or as building mortar, etc. since the early Mesopotamians. Mystical and religeous connotations and powers were often given to seepage fires in antiquity and even in modern times, and various unsuccessful attempts were made to extinguish the "eternal fires" in Kirkuk during World War II as they constituted a bright night beacon to guide Axis bombers onto the Kirkuk oil field and refinary. The problem was eventually overcome by strengthening the "ground defences" (Beydoun, 1997).

This great hydrocarbon loss leads to the outstanding question of whether the Zagros foreland basin has lost more oil than it has retained; what it has retained, nevertheless, is still very great, considering that the reserves remaining in Tertiary-created compressional structure of the basin in Iraq and SW Iran constitute 20-23\% of the estimated total oil reserves of the entire NE Arabian shelf! Considering that the cumulative oil production from all NE Arabian shelf countries from the start of production until the end of 1997 is estimated at some 302 billion barrels of oil (ca. 40 billion metric tonnes) (Oil and Gas Journal, 29 Dec. 1997), the implied ultimate recovery from the same region would amount to about 972 billion barrels of oil (ca. 129 billion metric tonnes) or, in other words, about $95 \%$ of the estimated remaining total world oil reserves (including those of the Arabian plate). A prodigious volume indeed!

Although estimated potential recoverable oil reserves from hydrocarbon solids such as tar sands (extra-heavy crude oils that are 


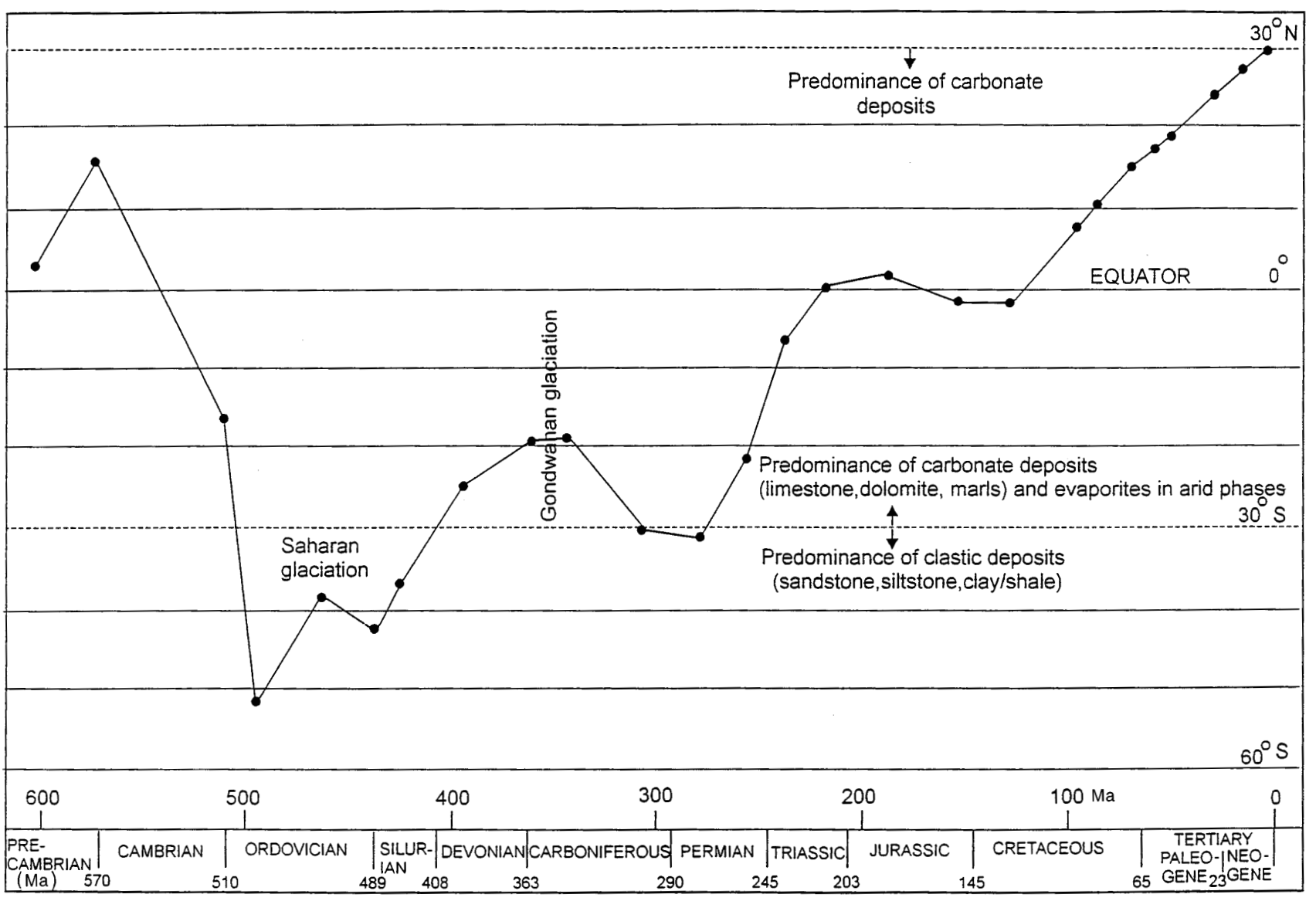

Figure 5 Generalized paleolatitude curve for the Kuwait/Basra area (Head of the Persian/Arabian Gulf) during the Phaneroroic (area positions based on Scotese and Golonka, 1992).

highly oxidized and extremely viscous which impregnate shallowly buried and outcropping sands in various parts of the world) are equivalent to nearly twice those from world crude oil reserves; and oil reserves recoverable from oil shales (argillaceous sediments containing immature or unspent kerogen) are estimated as being equivalent to remaining world crude oil reserves, but their extraction on a large scale is energy and water intensive and environmentally destructive. This automatically makes any large-scale extraction extremely expensive and undesirable. The return to the extraction of the other major remaining fossil fuel, namely coal, requires very deep mining for "good" grades, which is both economically no longer competitive and environmentally destructive, especially with its greater sulphurous atmospheric pollution.

Thus, among all the alternative fossil fuels nothing really viably can replace oil and gas, the "fluid" hydrocarbons, which are also the feedstock of the world's petrochemical industry. Moreover, regions which are as petroleum-rich as the Arabian plate will not magically appear to save the world in the 21 st century from the severe oil shortages that will take place, because all such potential regions have long since been identified and largely explored (except perhaps for the deep-water continental edges and the polar regions) and none of them have been blessed with the good combination of geological and morphological factors that make the Arabian plate so unique.

\section{Concluding remarks}

Oil (and gas) are finite resources in the sense that mankind is consuming them at rates many orders of magnitude greater than nature can renew them, with gas in general being more quickly renewable than oil (from biogenic and gas hydrate sources). Although there are sufficient proven oil reserves, albeit very localized and unevenly distributed around the world, to satisfy world demand at current consumption rates for another 43 years or so (and for longer with a switch to gas which can perform many of the functions now performed by oil), we should not sit back with the comfortable illusion that these resources will always be there. For certain, new oil and gas reserves will be added to those already proven and producible with the present-day technologies. Such reserves, however, will be difficult to locate because virtually all likely hydrocarbon-bearing sedimentary basins have been identified and explored to varying degrees and because virtually all huge fields ("megagiants": > 50 billion barrels oil recoverable; "supergiants": 5-50 billion barrels of oil recoverable; "giants": 0.5-5 billion barrels of oil recoverable) have already been found using conventional and improved technologies. In general, smaller-sized fields only will reward future efforts even with improved new technologies yet to be invented. Such new discoveries will be more costly and located in hostile environments of the offshore deep continental edges and in polar regions and will not be able to replenish the more rapidly diminishing reserves as demand exceeds supply on a planet with population explosions in Third World countries and newly industrialized nations demanding cheap energy to be competitive. The cost of finding these new reserves will rise, which will also mean a corresponding rise in the price of oil and gas as the demand exceeds the growing shortage in supply.

It is true that modern technologies such as horizontal drilling and practices such as infill, extension and multiple target drilling in producing fields and utilization of coil tubing have substantially increased and will continue to increase the amount of oil recoverable from poorer reservoirs and cut costs. It is true that enhanced oil recovery (EOR) methods will recover more oil from depleted or near depleted fields. It is also true that 3D and 4D seismic methods developed with advances in computer technology have and will continue 
to greatly enhance the clarity and visualization of the subsurface structural reality and hence lead to better successes in tapping smaller potential fields. But improvements to these technologies and techniques and discovery of other such cost-cutting exploration and development technologies/techniques need an immediate large input of Research and Development (R and D) funds. Unfortunately, such funding on a big scale has been choked off since the mid 1980s because oil prices have been steadily declining as supply continues to exceed demand in the short and short to medium terms and the oil industry is approaching the point where it has just about eked out all that can be extracted with the new technologies developed in the late 1970 s and early 1980s when research funding was no problem. The exploration game remains a big gamble and strategies are in constant need of reassessment; the saying "oil is first found in the mind" well illustrates this.

Thus, although hydrocarbons and especially oil are in plentiful supply at present and provide a cheap and readily available source of energy world-wide, they have also become the basis of our modern industrial civilization with nearly total dependence on this finite resource. Our future will indeed be very bleak when this resource begins to dry up. The sooner the serious search for viable dependable energy alternatives can begin, the less bleak the future of humankind will be. The petrochemical industry, however, will suffer greatly as soon as hydrocarbon resources begin to seriously dry out. Ironically, viable and dependable alternative energy sources are within our grasp. The examples are the commercial utilization of an unending energy source that bombards our planet daily from the sun, and the harnessing of an almost equally limitless other potential energy source, hydrogen, present all around us in the hydrosphere. What we lack is a sense of urgency and massive funding in order to achieve commercial viability in utilisation before the dwindling supplies of hydrocarbons begin to dry out, since lead times in $\mathrm{R}$ and $\mathrm{D}$ can be measured in decades. Unfortunately, such huge monetary investments are not forthcoming so long as oil prices remain suppressed and oil supplies remain plentiful. Limited $R$ and D projects for finding commercially competitive alternative energy source were embarked upon by the international oil industry and governmentsupported researchers in the industrial world during earlier oil shortage crises but these were abandoned as too costly soon after plentiful and cheap oil supplies returned. It thus has to be emphasized that we cannot, as humankind, afford to wait until the real irreversible oil crisis arrives to embark on serious research on the commercially viable alternative energy source; the time to plan and to act is NOW. Oil is too valuable a resource to simply burn as a fuel because it is (together with gas) the principal feedstock of our petrochemical and fertilizer industries and also a potentially major source for synthesizing proteins crucial to a world with rapidly increasing populations living below the poverty line. What hydrocarbons are left in the ground by the time the commercially viable alternative energy resources are in use should be earmarked for the essential purposes of feeding and making human life on this planet marginally better and not further squandering of this finite non-renewable resource by burning it as a very expensive fuel.

\section{Acknowledgements}

Dr. A. F. Abdel Rahman, Chairman of the Department of Geology, American University of Beirut, critically reviewed the manuscript and offered constructive suggestions which have improved the paper. Mrs. Huda Nisr Abdel Sater and Mr. Maroun Ijreiss of the same Department are thanked for typing the revised manuscript and drawing the figures respectively.

\section{References}

\footnotetext{
Beydoun, Z.R., 1986. The petroleum resources of the Middle East: a review. Journal of Petroleum Geology, 9:5-29.
}

Beydoun, Z.R., 1988. The Middle East: Regional Geology and Petroleum Resources . Scientific Press, Beaconsfield, U.K., 292p.

Beydoun, Z.R., 1991. Arabian Plate Hydrocarbon Geology and Potential a Plate Tectonic Approach. American Association of Petroleum Geologists Studies in Geology 33, 77p.

Beydoun, Z.R., 1993. Evolution of the northeastern Arabian plate margin and shelf, hydrocarbon habitat and conceptual future potential. Revue de l'Institut Français du Pétrole, 48:311-345.

Beydoun, Z.R., 1995. Productive Middle East clastic oil and gas reservoirs: their depositional settings and origin of their hydrocarbons. Special Publication of the International Association of Sedimentologists, 22: 331-354.

Beydoun, Z.R., 1997. Prehistoric, ancient and mediaeval occurrences and uses of hydrocarbons in the Greater Middle East region. Journal of Petroleum Geology, 20:91-95.

Beydoun, Z.R., Hughes Clarke, M.W. and Stoneley, R., 1992. Petroleum in the Zagros basin: a late Tertiary foreland basin overprinted onto the outer edge of a vast hydrocarbon-rich Paleozoic-Mesozoic passive margin shelf. In R. Macqueen and D. Leckie, eds, Foreland Basins and Foldbelts, American Association of Petroleum Geologists Memoir 55, Ch. 11, 309-339 .

Bois, C., Bouché, P., and Pelet, R., 1982. Global geologic history and distribution of hydrocarbon reserves. American Association of Petroleum Geologists Bulletin 66: 1248-1270.

Dunnington, H.V., 1974. Aspects of Middle East oil geology. In Geological Principles of World Oil Occurrences Proceedings, Banff, Alberta, $89-156$.

Grunau, H.R., 1977. Generation, migration, entrapment and retention of hydrocarbons in the Middle East. Petroleum Times (June 10):33-43.

Hempton, M.R., 1987. Constraints on Arabian plate motion and extensional history of the Red Sea. Tectonics, 6:687-705.

McGoon, L.B. and Dow, W.G., 1994. The petroleum system. In L.B. McGoon and W.G. Dow, eds, The Petroleum System-From Source to Trap, American Association of Petroleum Geologists Memoir, 60:3-24.

Murris, R.J., 1980. The Middle East: stratigraphic evolution and oil habitat. American Association of Petroleum Geologists Bulletin, 64:597-618.

Quennell, A.M., 1958. The structural and geomorphic evolution of the Dead Sea Rift. Quarterly Journal of the Geological Society of London, 114:1-24.

Quennell, A.M., 1984. The western Arabian rift system. In J.E. Dixon and A.R.F. Robertson eds, the Geological Evolution of the eastern Mediterranean,; Geological Society Special Publication, 17:775-788.

Riché, P.H. and Prestat, B., 1979. Paléogéographie du Cretacé Moyen du Proche Orient et sa signification pétrolière. 10th. World Petroleum Congress Proceedings, Bucharest, 2:57-75.

Scotese, C.R. and Golonka, J. 1992. Paleogeographic Atlas. Paleomap Project, University of Texas at Arlington.

Stoneley, R., 1990. The Middle East Basin: a summary overview. In J. Brookes, ed., Classic Petroleum Provinces, Geological Society Special Publication, 50:293-298.

The late Ziad Beydoun was professor of geology at the American University of Beirut. He was a graduate of the University of Oxford and his professional carreer spans 50 years mainly devoted to the geology of the Middle East. He began his field investigations in 1948 with the Iraq Petroleum and Associated Companies and worked in most of the countries of the Middle East. From 1964, when he joined the American University of Beirut, he was also associated with Marathon International Oil Co. as Middle East Geological Advisor.

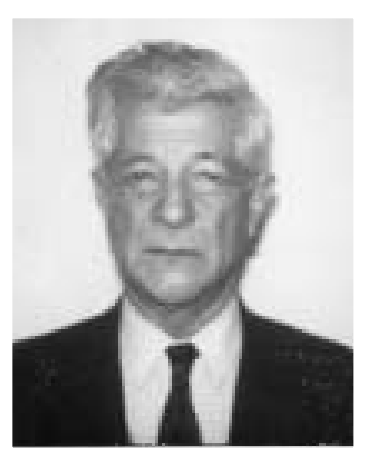

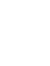

